\title{
A new formula to calculate the medicine dosage in function of the weight
}

\author{
Uma nova fórmula para calcular a dosagem de medicamentos em função do peso \\ Una nueva fórmula para calcular la dosis del medicamento en función del peso
}

Received: 05/28/2021 | Reviewed: 06/06/2021 | Accept: 06/06/2021 | Published: 06/22/2021

\author{
Dyecika Souza-Couto \\ ORCID: https://orcid.org/0000-0002-1801-7666 \\ Federal University of Alfenas, Brazil \\ E-mail: dyecikacouto99@gmail.com \\ Amanda Barcelos-Faria \\ ORCID: https://orcid.org/0000-0001-5008-4044 \\ Federal University of Alfenas, Brazil \\ E-mail: amandabarcelosfaria@gmail.com \\ Emmanuel Freitas-Ferreira \\ ORCID: https://orcid.org/0000-0002-9399-9380 \\ Federal University of Alfenas, Brazil \\ E-mail: emmanuelfferreira07@gmail.com \\ Tales Alexandre Aversi-Ferreira \\ ORCID: https://orcid.org/0000-0002-4417-7209 \\ Federal University of Alfenas, Brazil \\ E-mail: tales.ferreira@unifal-mg.edu.br
}

\begin{abstract}
A problem in relation to medicine concentration is linked to difference of age of the patients when the medicine was formulated for a pattern age, for instance, for adults. The use of this kind of medicine for children must be calculate correctly and some formulas based in the empirical mathematical methods were suggested and they are used nowadays; however, patients form a same pattern age but with different weight shows a different biotype and requires a different concentration of medicines, as well as the children and the elderly people. According, in this work, based on the mechanical mathematical model using the relation area/volume, a more exact calculus including the metabolism, was proposed to generate a more accuracy formula to calculate the medicine concentration for children and for people of different weight.
\end{abstract}

Keywords: Drug dosage calculations; Relation área/volume; Mathematics model.

\section{Resumo}

Um problema em relação à concentração do medicamento está relacionado à diferença de idade dos pacientes quando o medicamento foi formulado para uma idade padrão, por exemplo, para adultos. $\mathrm{O}$ uso deste tipo de medicamento para crianças deve ser calculado corretamente e algumas fórmulas baseadas nos métodos matemáticos empíricos foram sugeridas e são utilizadas atualmente; entretanto, pacientes com um mesmo padrão de idade, mas com peso diferente, apresentam biótipo diferente e requerem concentração de medicamentos diferente, assim como crianças e idosos. Nesse sentido, neste trabalho, com base no modelo matemático mecânico utilizando a relação área / volume, um cálculo mais exato incluindo o metabolismo, foi proposto para gerar uma fórmula mais acurada para calcular a concentração do medicamento para crianças e para pessoas de diferentes pesos.

Palavras-chave: Cálculos da dosagem de medicamento; Relação área/volume; Modelo matemático.

\section{Resumen}

Un problema con la concentración del fármaco está relacionado con la diferencia de edad de los pacientes cuando el fármaco se formuló a una edad estándar, por ejemplo, para adultos. El uso de este tipo de medicamentos para niños debe calcularse correctamente y se han sugerido y se utilizan actualmente algunas fórmulas basadas en métodos matemáticos empíricos; sin embargo, los pacientes con el mismo patrón de edad, pero con diferente peso, tienen un biotipo diferente y requieren diferentes concentraciones de fármaco, así como los niños y los ancianos. En este sentido, en este trabajo, a partir del modelo matemático mecánico utilizando la relación área / volumen, se propuso un cálculo más preciso que incluye el metabolismo, para generar una fórmula más precisa para calcular la concentración del fármaco para niños y personas de diferentes pesos.

Palabras clave: Cálculo de dosificación de drogas; Relación área/volumen; Modelo matemático. 


\section{Introduction}

Notwithstanding the valorous action of the medicine in the corporal metabolism, there is an important restriction regarding the ability to obtain the correct effective concentration, especially for use in children (Lesar, 1998; Ernest, 2007; Ivanovska et al., 2014; Walsh, 2016).

Many studies on the dosing of medicines have been performed and continue to be carried out, mainly due to difficulties in determining the optimum concentration of the active compound for use in adult, paediatric (Balakrishan et al., 2006a; Salunke et al., 2017; Preis and Breikreutz, 2017) and geriatric (Liu et al., 2014) patients.

Indeed, errors associated with the dosage of medicine for children, adults and elderly patient represent the most common reasons for adverse drugs events in healthcare situations (Lesar, 1998). In addition, the misuse of medicines is an important issue in the health science field (Andrade et al., 2020).

Some articles have cited dosage errors in the use of medicines designed for adults in children (Balakrishan et al., 2006a; Balakrishan et al., 2006b; Liu et al., 2014; Salunke et al., 2017; Preis \& Breikreutz, 2017). Determining the correct adjustment of the medicine dosage is a complex problem, as physicians must also consider aspects such as metabolic, physiological and weight differences among individuals (Lesar, Briceland and Stein 1997) and the polarity of drugs (AversiFerreira, 2014). Furthermore, an increase in the production of a number of the drugs could generate additional problems regarding toxicology (Silva, Jesus \& Branco, 2020).

There seems to be no consensus on how to solve this important aspect of medicine use (Bates et al., 1995), mainly in relation to the performance of standardised tests by physicians (Bates et al., 1995; Lesar, 1998). On the other hand, paediatricians use tables to determine the correct drug dosage for children; however, adverse outcomes were found to arise from the incorrect use of equations (Bates et al., 1995) in about 15\% of studies (Lesar, 1998).

For a long time, researchers have been trying to solve problems associated with the dosage of medicines for children (Lack \& Stuart-Taylor, 1991). However, problems related to weight differences among adult patients have been little explored.

For children, many empirical formulas have been used to determine medicine concentrations; for instance, the Salisbury, body surface area (BSA) (Lack \& Stuart-Taylor, 1991), Young, Martinet and Cowling rules (Brasil, 2008).

Several critical studies have identified problems with the use of these formulas and suggested modifications (Lack \& Stuart-Taylor, 1991). In fact, weight, body surface, metabolism and height have been proposed as the basis for calculating medicine concentrations for children (Ernest et al., 2007).

One problem related to the use of formulas for medicine dosage calculations is whether to use a direct mathematic relationship or an exponential one (Lack \& Stuart-Taylor, 1991).

In fact, the relationship between area and volume was studied by Galileo (1638), who discussed differences in the weight (weight is directly proportional to volume for the same material) of animals and objects such as ships and bones and discovered that weight increases to a greater extent than the area for the same object.

In this way, a mock-up been increased for a real size, for instance, a boat would sink because the weight increase raised to third power and the area increase raised to second power, then the relationship between the area to volume is raised to $2 / 3$ power.

Thus, the relationship between area and weight has been known since the time of Galileo. Hypothetically, this relationship could be used to generate a mathematic function for the concentration of medicines, such as in allometric studies of inter- and intraspecies differences (Gould, 1969).

Therefore, the aim of this study was to compare existing drug concentration formulas with one based on the area/volume relationship for weight differences between adults and differences in drug concentrations between children and adults. 


\section{Methodology}

A literature search was performed with the terms "medicine concentration", "medicine concentration calculus" and "pediatric medicine concentration calculus". From the literature, formulas for calculating paediatric medicine concentration were found for medicines that were made only for adults, not for children. These formulas were empirical; therefore, they were based on available data and used the patient's age as the basis for the calculation. Only one paper considered the superficial body area of children to determine the medicine concentration (i.e., a mechanical approach into the rigors mathematical model) (Rodman, 1994).

Non-paper articles were found by searching the PubMed, Elsevier, Scielo and Scopus databases for articles on different concentrations of medicines considering weight variations of people in different phases of life, such as in infancy, adulthood and late adulthood (i.e., linked to aging).

A relationship between the weight was obtained in function of the mass variation power to $2 / 3$ because the variation of the weight occurred according to the increase/decrease of the power 2 for area and power 3 for weight.

It is important to consider that mass is directly proportional to volume. Then, we adequate the area/volume formula to calculate the medicine concentration for the aging linked to weight and, it comes from the relation:

\section{\begin{tabular}{|c|} 
Subject dosage \\
Pattern purpose medicine
\end{tabular}$=\frac{(\text { weight of the subject })^{2 / 3}}{(\text { weight of the pattern purpose medicine })^{2 / 3}}$}

Data for the concentrations of many medicines for children were compared using the empirical formulas and the formula proposed in this article.

We studied the differences and similarities between these formulas for calculating the medicine dosage for children in order to test our formula. Subsequently, the reliability of the proposed area/volume formula was determined.

StatPlus:mac (AnalystSoft Inc., 2020) software was used to calculate the coefficient of correlation at $p<0.05$ (Figure $1)$.

\section{Results}

The Young, Cowley and Martinet formulas (Elias and Mariano, 2004; Brasil, 2008) are as follows:

Young

pediatric dose: $\frac{\text { child's age }}{\text { child's age }+12}$ x adult dose

Cowling

$X: \frac{\text { child's age }+1^{\prime}}{24} x$ adult dose

$\mathrm{X}$ : number of times that the paediatric dose is lower than the adult dose

Martinet

$Y=\frac{\text { child'sage }+1}{20} \times 100$

Y: percentage of adult dose. 
These formulas are empirical, and they use the child's age to determine the paediatric dosage. In this work, we used the metabolic approach linked to the area/volume relationship to propose a new formula, as follows:

$$
\text { subject dosage }=\frac{\text { medicine dose } x(\text { weight of the subject })^{2 / 3}}{(\text { weight of the pattern purpose medicine })^{2 / 3}}
$$

To verify the reliability of these formulas, we tested 150 medicines designed for adults, 50 of which are shown in Table 1, to compare the results obtained between the commonly used empirical formulas and the area/volume formula proposed in the current article. The medicine concentrations are made for a healthy adult weighing $70 \mathrm{~kg}$ and $1.70 \mathrm{~m}$ tall. The adult medicine concentrations were used to calculate the concentration of the same medicine for a child aged 10 years old.

Table 1: Comparative data among the empirical formulas and the mechanical formula proposed in this article. Note: * MAD= maximum adult dose. $* \mathrm{MPD}=$ maximum pediatric dose. $* \mathrm{AW}=$ adult weight. $* \mathrm{PW}=$ pediatric weight. $* \mathrm{CA}=$ child's age. $* \mathrm{FC}=$ Cowling's Formula. *FY= Young's Formula. *FM= Martinet's Formula. *FT= Formula Test. $* / /=$ there were no studies. $*=$ was not specified in the package leaflet.

\begin{tabular}{|c|c|c|c|c|c|c|c|c|c|}
\hline \multirow[t]{2}{*}{ Medicamento } & MAD & MPD & AW & PW & CA & FC & FY & FM & FT \\
\hline & $(\mathrm{mg})$ & $(\mathrm{mg})$ & $(\mathrm{kg})$ & $(\mathrm{kg})$ & $\begin{array}{c}\text { (years } \\
\text { old) }\end{array}$ & $(\mathrm{mg})$ & $(\mathrm{mg})$ & $(\mathrm{mg})$ & $(\mathrm{mg})$ \\
\hline Atenolol & 100 & // & 70 & 31 & 10 & 45,83 & 41,67 & 55 & 58,09 \\
\hline Diazepan & 20 & // & 70 & 31 & 10 & 9,167 & 9,09 & 11 & 11,62 \\
\hline Azithromycin & 500 & 300 & 70 & 31 & 10 & 229,167 & 227,27 & 275 & 290,5 \\
\hline Cephalexin & 4000 & 1500 & 70 & 31 & 10 & 1833,33 & 1818,18 & 2200 & 2324 \\
\hline Ibuprofen & 3200 & 800 & 70 & 31 & 10 & 1466,67 & 1454,54 & 1760 & 1859,2 \\
\hline Dipyrone & 4000 & 3000 & 70 & 31 & 10 & 1833,33 & 1818,18 & 2200 & 2323,99 \\
\hline Codeine phosphate & 360 & 60 & 70 & 31 & 10 & 165 & 163,63 & 198 & 209,16 \\
\hline Acetylsalicylic acid & 500 & 100 & 70 & 31 & 10 & 229,17 & 227,27 & 275 & 292,71 \\
\hline Captopril & 150 & $/ /$ & 70 & 31 & 10 & 68,75 & 68,18 & 82,5 & 40,99 \\
\hline Sertraline & 200 & 50 & 70 & 31 & 10 & 91,66 & 90,91 & 110 & 116,19 \\
\hline Amoxicilin & 6000 & 4650 & 70 & 31 & 10 & 2750 & 2727,27 & 3300 & 3560 \\
\hline Simethicone & 500 & - & 70 & 31 & 10 & 229,17 & 227,27 & 275 & 296,72 \\
\hline Dexamethasone & 15 & - & 70 & 31 & 10 & 6,875 & 6,82 & 8,25 & 8,9 \\
\hline Acetominophen & 4000 & 2325 & 70 & 31 & 10 & 1833,333 & 1818,182 & 2200 & 1093,245 \\
\hline Dimenhydrinate & 400 & 150 & 70 & 31 & 10 & 183,333 & 181,818 & 220 & 109,325 \\
\hline Domperidone & 40 & 35 & 70 & 31 & 10 & 18,333 & 18,182 & 22 & 10,932 \\
\hline Fluoxetine & 80 & - & 70 & 31 & 10 & 36,667 & 36,364 & 44 & 21,865 \\
\hline Nimodipine & 90 & - & 70 & 31 & 10 & 41,250 & 40,909 & 49,5 & 24,598 \\
\hline Atorvastatin & 80 & 20 & 70 & 31 & 10 & 36,667 & 36,364 & 44 & 21,865 \\
\hline Losartan & 100 & - & 70 & 31 & 10 & 45,833 & 45,455 & 55 & 27,331 \\
\hline Omeprazole & 120 & 40 & 70 & 31 & 10 & 55,000 & 54,545 & 66 & 32,797 \\
\hline Nimesulide & 200 & 77,5 & 70 & 31 & 10 & 91,667 & 90,909 & 110 & 54,662 \\
\hline
\end{tabular}




\begin{tabular}{|c|c|c|c|c|c|c|c|c|c|}
\hline Ketoprofen & 300 & - & 70 & 31 & 10 & 137,500 & 136,364 & 165 & 81,993 \\
\hline Betametashone & 8 & 7,75 & 70 & 31 & 10 & 3,667 & 3,636 & 4,4 & 2,186 \\
\hline Prednisone & 60 & 62 & 70 & 31 & 10 & 27,500 & 27,273 & 33 & 16,399 \\
\hline Scopolamine & 100 & 100 & 70 & 31 & 10 & 45,833 & 45,455 & 55 & 27,331 \\
\hline Loratadine & 10 & 10 & 70 & 31 & 10 & 4,583 & 4,545 & 5,5 & 733,000 \\
\hline Ciprofloxacin & 1500 & 1500 & 70 & 31 & 10 & 687,500 & 681,818 & 825 & 409,967 \\
\hline Levofloxacin & 1000 & - & 70 & 31 & 10 & 458,333 & 454,545 & 550 & 273,311 \\
\hline Fexofenadine & 180 & 60 & 70 & 31 & 10 & 82,500 & 81,818 & 99 & 49,196 \\
\hline Carbamazepine & 2000 & 1000 & 70 & 31 & 10 & 916,667 & 909,091 & 1100 & 546,623 \\
\hline Risperidone & 16 & - & 70 & 31 & 10 & 7,333 & 7,273 & 8,8 & 4,373 \\
\hline Zidovudine & 300 & 160 & 70 & 31 & 10 & 137,500 & 136,364 & 165 & 81,993 \\
\hline Oseltamivir & 150 & 120 & 70 & 31 & 10 & 68,750 & 68,182 & 82,5 & 40,997 \\
\hline Fluconazole & 400 & 372 & 70 & 31 & 10 & 183,333 & 181,818 & 220 & 109,325 \\
\hline Albendazole & 400 & 400 & 70 & 31 & 10 & 183,333 & 181,181 & 220 & 109,325 \\
\hline Metronidazole & 2000 & 697,5 & 70 & 31 & 10 & 916,667 & 909,091 & 1100 & 546,623 \\
\hline Diclofenac & 200 & - & 70 & 31 & 10 & 91,667 & 90,909 & 110 & 54,662 \\
\hline Piroxicam & 40 & - & 70 & 31 & 10 & 18,333 & 18,182 & 22 & 10,932 \\
\hline Etoricoxib & 90 & - & 70 & 31 & 10 & 41,250 & 40,909 & 49,5 & 24,598 \\
\hline Metformin & 2550 & 2000 & 70 & 31 & 10 & 1168,750 & 1159,091 & 1402,5 & 696,944 \\
\hline Pioglitazone & 45 & - & 70 & 31 & 10 & 20,625 & 20,455 & 24,75 & 12,299 \\
\hline Furosemide & 80 & 40 & 70 & 31 & 10 & 36,667 & 36,364 & 44 & 21,865 \\
\hline Methyldopa & 3000 & - & 70 & 31 & 10 & 1375,000 & 1363,636 & 1650 & 819,934 \\
\hline Chlortalidone & 200 & 50 & 70 & 31 & 10 & 91,667 & 90,909 & 110 & 54,662 \\
\hline Acetylcysteine & 600 & 400 & 70 & 31 & 10 & 275,000 & 272,727 & 330 & 163,987 \\
\hline Digoxin & 1,5 & 0,775 & 70 & 31 & 10 & 0,688 & 0,682 & 0,825 & 0,410 \\
\hline Clopidogrel & 300 & - & 70 & 31 & 10 & 137,500 & 136,364 & 165 & 81,993 \\
\hline Ciprofibrate & 100 & - & 70 & 31 & 10 & 45,833 & 45,455 & 55 & 27,331 \\
\hline Cimetidine & 2400 & 930 & 70 & 31 & 10 & 1100,000 & 1090,909 & 1320 & 655,947 \\
\hline
\end{tabular}

Source: Authors.

A regression test was performed to compare all formulas to each other. The correlation coefficient $\left(\mathrm{R}^{2}\right)$ indicates a strong correlation between the empirical formulas and the mechanical one described here (Figure 1). 
Figure 1: Graphics and coefficient of correlation values $\left(\mathrm{R}^{2}\right)$ for each formula compared two by two to verify the reliability of the empirical formulas each other and them with the mechanical formula proposed in this article. FC= Cowling Formula, FY= Young Formula, FM= Martinet Formula, FT= Formula Test.

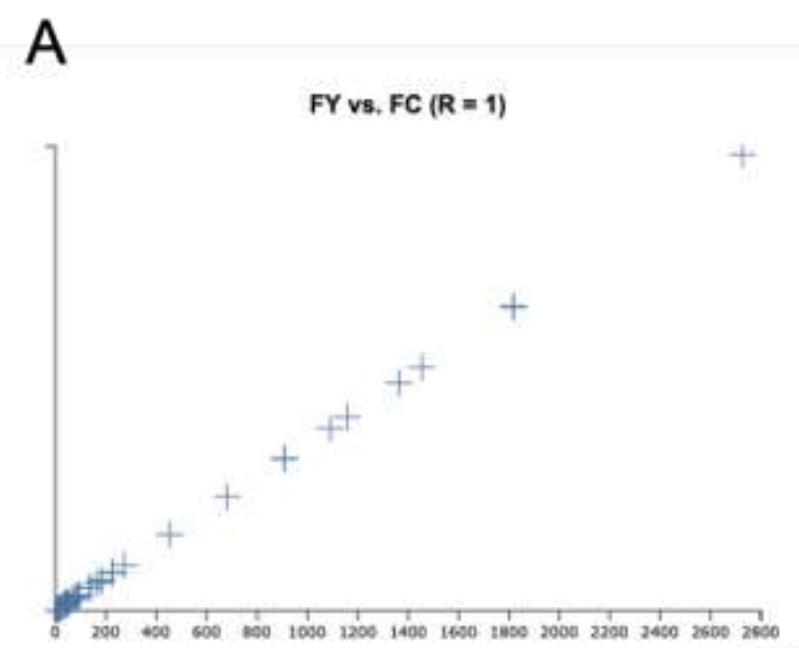

\section{B}

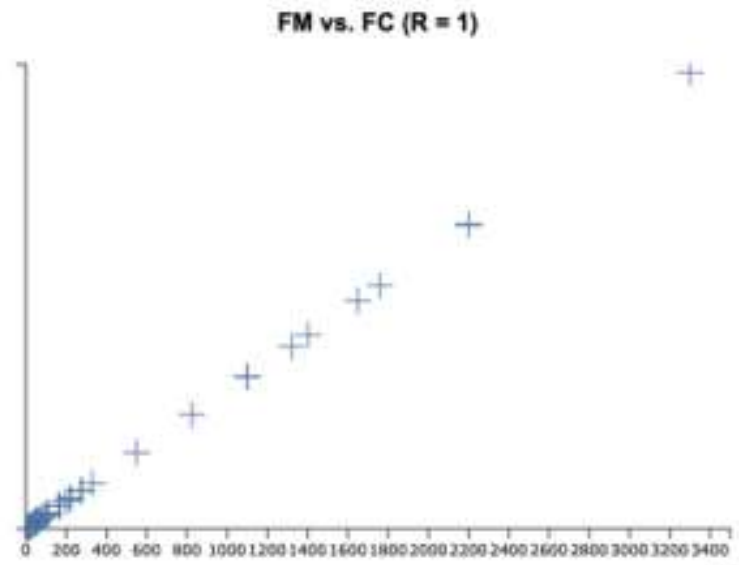

$\mathrm{mg}$

\section{C}

FT vs. $F C(R=0,99991)$

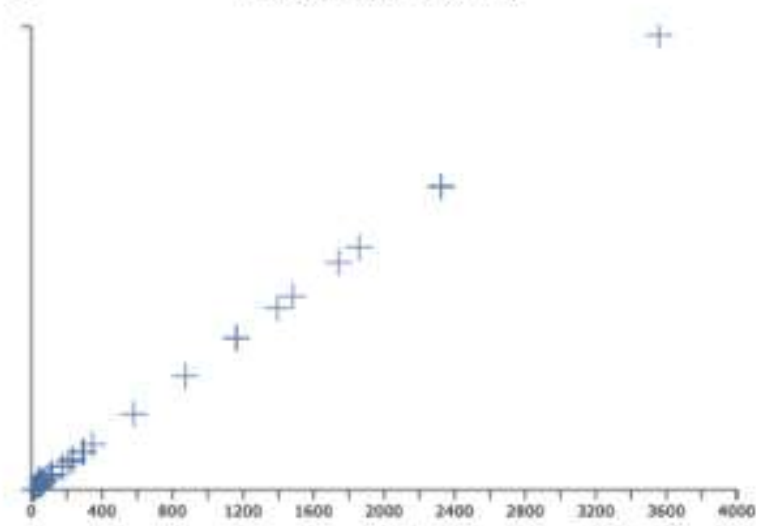

$\mathrm{mg}$

\section{E}

$F M$ vs. $F Y(R=1)$

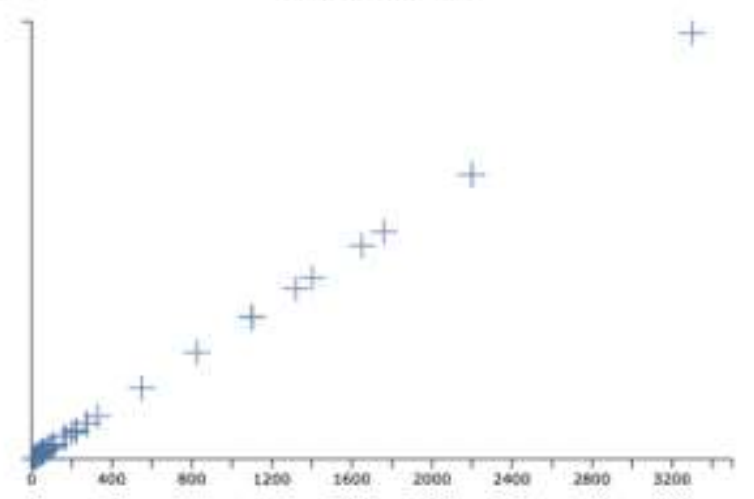

D

FT vs. FM $(R=0,99991)$

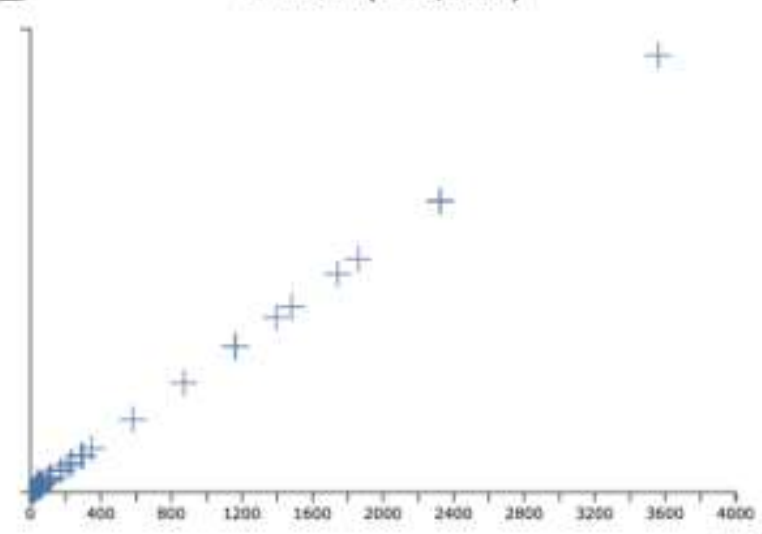

$\mathrm{mg}$

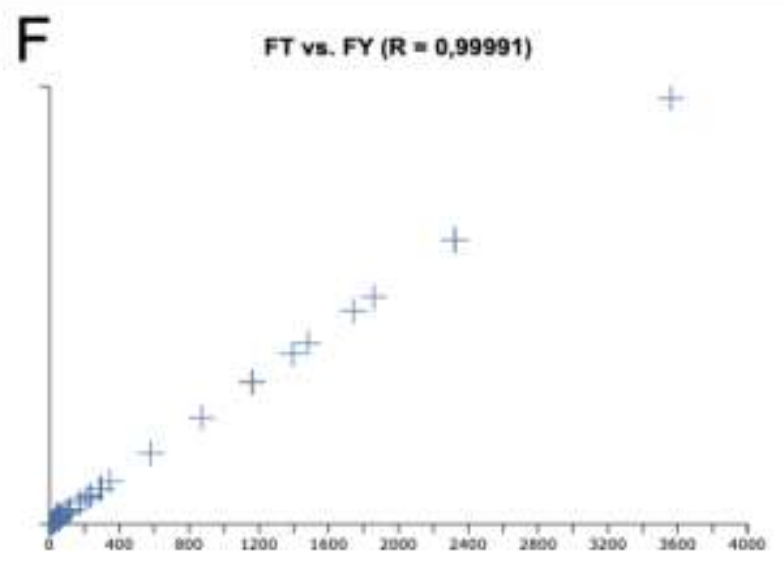

$\mathrm{mg}$

Source: Authors. 


\section{Discussion}

According, the area/volume analysis targeted to metabolism study, was adapted to associate difference of the medicine concentration, obviously considering the rate area/volume between the bodies mass.

Until now, the formulas used to calculate the medicine dosage for children were derived from an empirical mathematical model based on data not necessarily associated with metabolism. Metabolism is the basis of medicine formulations for patients; therefore, the age of children and adults and were conveniently used to fit to empirical data should not be used for adults of different weights, as they will have different metabolisms.

A mechanical formula considering the metabolism and area/volume relationship could be used to determine the dosage of medicines designed for adults but used in children, for children of different weights, and for adults and elderly adults with a different metabolism and/or bodyweight.

Indeed, the relationship between area and volume is the basis for metabolism studies for investigating animal evolution and metabolism in terms of ecology, but it could also be used for the same species at different stages of development in a direct mathematical and physiological sense.

For a long time, formulas from empirical models have been used to adapt the concentration of medicines for children, and our mechanical formula shows an identical $\mathrm{R}^{2}$ to previously cited formulas (Table 1 and Figure 1) for adapting medicines for children. As our mechanical formula uses metabolic data, one strength is that it could be used for adults of different weights, in addition to children and elderly people.

However, for elderly patients, there is an additional problem that must be considered. Some cases present an increase in bodyweight along with a decrease in metabolism, representing a physiological discrepancy in the formula.

The solution to this problem is to insert the correction factor $(\Delta)$ into the formula (see equation below); however, this correction factor must be based on experimental data from continuous studies of the effects of medicines in elderly patients, which was not performed in this work.

\section{\begin{tabular}{|c|} 
Subject dosage \\
Pattern purpose medicine
\end{tabular}$=\frac{(\text { weight of the subject })^{\frac{2}{3}} \cdot \Delta}{(\text { weight of the pattern purpose medicine })^{2 / 3}}$}

Accordingly, the correction factor must be less than 1 for elderly patients because their metabolism is slower than that of adults. However, for children and adults with normal, excess or slightly increased bodyweight, our formula considers those variations.

\section{Conclusion}

The mechanical formula proposed in the current study can be used to obtain the optimal drug concentration for children and adults, with adjustments for the elderly and adults of any age. This formula represents a reliable basis for the general use of drugs in individuals who do not fit the specifications for the standard adult dose specified by the manufacturer. It is important to state that the mechanical formula proposed here is based on metabolic data, i.e., the area/volume correlation, and the fit of the graphs, shown by the correlation coefficient, indicates the reliability of this formula for use in people other than children, but also children with abnormal weight as adult with abnormal weight.

Other studies are necessary to (1) verify the details for variations in the use of our formula, (2) verify the correction factor $(\Delta)$ for elderly people, and (3) verify discrepancies among individuals based on their unique characteristics. 


\section{Acknowledgments}

The authors thank to anonymous reviewers by the comments that increase the quality of this manuscript.

\section{References}

Andrade, S. M. de, Cunha, M. A., Holanda, E. C., Coutinho, G. S. L., Verde, R. M. C. L., \& Oliveira, E. H. de (2020). Characterization of the profile of drug intoxications by self-medication in Brazil, from 2010 to 2017. Research, Society and Development, 9(7), e236973952.

Aversi-Ferreira, T. A. (2014). Biologia Celular e Molecular. (2a ed). Editora Átomo.

Balakrishnan, K., et al. (2006a). Pediatric licensing status and the availability of suitable formulations for new medical entities approved in the United States between 1998 and 2002. Journal of Clinical Pharmacology. 46(9), 1038-1043.

Balakrishnan, K., et al. (2006b). Establishing a baseline for the monitoring of medicines availability for children in the UK: 1998-2002. British Journal Clinical Pharmacology. 63(1), 85-91.

Bates, D. W., et al. (1995). Relationship Between Medication Erros and Adverse Drug Events. Journal of General Internal Medicine. 10(4), $199-205$.

Brasil, Ministério da Saúde. (2008). Formulário Terapêutico Nacional 2008.

Elias, G. P., \& Mariano, R. C. (2004). Estudo comparativo de fórmulas disponíveis para o cálculo de doses medicamentosas infantis. Rev. Íbero-americana de Odontopediatria \& Odontologia. 7(38), 347-348.

Ernest, T. B, et al. (2007). Developing paediatric medicines: identifying the needs and recognizing the challenges. Journal Pharmacy and Pharmacol. 59(8), 1043-1055.

Galilei, G. (1638). Discorsi e Dimostrazioni Matematiche intorno à due nuove scienze, Attinenti ala Mecanica \& i Movimenti Local.

Gould, S. J. (1969). An evolutionary microcosm: Pleistocene and recent history of the land snail P. (Poecilozonites) in Bermuda. Bull. Mus. Comp. Zool. 138, 407-532.

Ivanovska, V., et al. (2014). Pediatric drug formulations: a review of challenges and progress. Pediatrics. 134(2), 361-372.

Lack, J. A., \& Stuart-Taylor, M. E. (1991). Calculation of drug and body surfasse área of children. Bristish Journal Anaesthesia, 78, 601-605.

Lesar, T. S. (1998). Errors in the use of medication dosage equations. Archives of Pediatrics and Adolescent Medicine. 152, $340-344$.

Lesar, T. S., Bricelnad, L. \& Stein, D. (1997). Factors Related to Errors in Medication Prescribing. Journal of the American Medical Association. 277(4), 312317.

Liu, F., et al. (2014). Patient-centred pharmaceutical design to improve acceptability of medicines: similarities and differences in paediatric and geriatric populations. Rev. Drugs. 74(16), 1871-1889.

Preis, M., \& Breitkreutz, J. (2017). Pediatric drug development and dosage form design. AAPS PharmSciTech. 18(2), 239-240.

Rodman, J. H. (1994). Pharmacokinetic variability in the adolescent: implications of body size and organ function for dosage regimen design. Journal of Adolecent Healt. 15(8), 654-662.

Salunke, S., et al. (2017). European Paediatric Formulation Initiative (EuPFI). European Paediatric Formulation Initiative (EuPFI) - formulating ideas for better medicines for children. Rev. AAPS PharmSciTech. 18(2), 257-262.

Silva, M. de A., Jesus, L. L. S., \& Branco, A. C. da S.C. (2020). Drug poisoning: a study over secondary data in Brazil. Research, Society and Development. 9(2), e200922254.

Walsh, J. (2017). Reflection on the pharmaceutical formulation challenges associated with a paediatric investigation plan for an off-patent drug. Rev. AAPS PharmSciTech. 18(2), 250-256. 